\title{
SUFIS, SHRINES, AND THE STATE IN TAJIKISTAN
}

This forum posits a range of relationships between sacred geographies and forms of identification across Eurasia, whether inflected religiously, ethnically, or nationally. I have written previously about the sacred geography of Tajikistan in regard to two large shrine complexes - Hazrati Amirjon in the southern Tajik city of Kulob and Hazrati Mavlono outside of the country's capital and urban centre, Dushanbe - both revered and frequented by the male, Naqshbandi and Qodiri Sufi groups who formed the basis of my book (Gatling 2018). Hazrati Amirjon and Hazrati Mavlono are not necessarily emblematic or metonymic of sacred space in Tajikistan. In terms of absolute quantity, the vast majority of shrines catalogued by Tajik researchers surround natural features, such as sacred springs, trees, caves, etc. (Muzaffarī et al. 2007: 10), whereas Hazrati Amirjon and Hazrati Mavlono hold the graves of figures of transnational Muslim importance. What is relevant about Hazrati Amirjon and Hazrati Mavlono is that both sites illustrate contrasting approaches to the state administration over sacred space in Tajikistan. Although both accommodate pilgrims, Hazrati Amirjon primarily exists under the aegis of the Ministry of Culture as a museum and heritage site, while Hazrati Mavolono operates as an active congregational mosque, with its leadership appointed by the State Committee for Religious Affairs (Komitai oid ba korhoi din).

Recent ethnographic scholarship on politics in Central Asia has emphasised the performative dimensions of state governance and the ways that ordinary people constitute the political in repeated actions and negotiations (Adams 2010; Reeves et al. 2014). In this frame the state is not a pre-existing entity, but rather is performed into being through acts of signification. As anthropologists well know, repeated performances hold the power to shape subjectivities, to the extent that the region's authoritarian regimes' almost hegemonic control over religious discourse holds the capacity to shape the terms of being Muslim in Eurasia (Rasanayagam 2011: 121). If the political is performed into being and performances are constitutive of particular religious dispositions, then the contrasting politics of spectacle and control at shrine sites such as Hazrati Amirjon and Hazrati Mavlono offer test cases for how authoritarian approaches to governing Islam affect Central Asian believers on the ground. Hazrati Amirjon and Hazrati Mavlono are particularly compelling in that we can use them to chart the efficacy of state projects to connect sacred geography to state-endorsed forms of national belonging. Hazrati Amirjon and Hazrati Mavlono allow us to explore convergences between sacred spaces, devotional practices, state heritage projects, museumification, official religious discourse, and everpresent performative politics.

Hazrati Amirjon, situated in Kulob city centre, holds the grave of Mir Saiid Alii Hamadoni (1314-1384), a celebrated Sufi of the Kubraviya path best known for his missions to convert Kashmir to Islam. Hamadoni is among those figures from Muslim history buried in Tajikistan that are widely revered outside of the republic. Hazrati Amirjon is emblematic of the museumification of shrine space in the country. I have previously argued how Hamadoni's shrine works as a carefully curated artefact of historical Sufism, for which the Ministry of Culture acts as conservator (Gatling 2018: 36-40). Although Hamadoni is a figure of transnational importance to many Sufi lineages, Sufism at the shrine exists only as national cultural heritage. A spartan museum welcomes visitors to the shrine complex. The grounds themselves conjure more of an archaeological park than 
a site of active religious importance. Placards note the location of a medieval kiln, for instance. The Ministry of Culture attempts to proscribe completely many of the activities that would ordinarily exist on shrine day, for example bringing wild rue and water for blessing, reciting the Qur'an, or seeking the saint's intercession. Museumification seems to be the primary goal - not simple curtailment of devotional practice - in that numerous other sacred sites exist in the environs of Kulob at which such activities engender no sanction. Because Hazrati Amirjon is maintained by the Ministry of Culture as commensurate with other sites of historical importance around the republic, Islam too exists as heritage object and is rendered as a feature of Tajik national identity that organs of the state can muster toward their performative ends.

Hazrati Mavlono, situated in the eastern suburbs of Dushanbe at the edge of Tajikistan's main international airport's runway, is the burial place of Yaqubi Charkhi (13581447). Like Hamadoni, Charkhi is an early and influential figure in the history of Central Asian Sufism and is well known and revered outside of Tajikistan. What is different about Hazrati Mavolono is that, unlike Hamadoni's shrine, Hazrati Mavlono still functions as a congregational mosque with hundreds of pilgrims, some from Afghanistan and other countries in the region, visiting its grounds every week for shrine day. At the time of my last visit, in 2014, Friday prayers hosted so many congregants that the large shrine grounds were seemingly completely filled, with some worshippers resorting to praying outside of its gates. I have previously written about the expansive shrine-day market that supports pilgrims' activities (Gatling 2018: 103-109). At Hazrati Mavlono, the spectacular state's heritage-inflected performative politics seem completely absent, save for the text of the imomi khatib's Friday sermons as mandated by the State Committee for Religious Affairs. The one open accommodation to the state's on-going securitisation of Islam was the closure of the shrine's madrasa in 2008.
State projects to control Muslim piety and active reverence for sacred geography in contemporary Central Asia have been well investigated by anthropologists (for example KehlBodrogi 2008; Rasanayagam 2011; Féaux de la Croix 2016; Schwab and Bigozhin 2016), as has the broad historical importance of shrine space in Central Asian Muslim life (for example, Privratsky 2001; Louw 2007). Eren Tasar (2017: 226-240) has noted that already in the 1960s unitary Soviet policy toward restrictions on pilgrimages was experienced unevenly and was dependent entirely on the political will of local officials. Hazrati Amirjon and Hazrati Mavlono point toward the inverse. Tajik state restrictions on pilgrimages were uneven, while the experiences of Sufis stayed remarkably consistent. That distinction suggests a tentative answer to the convergences I posed at the outset of this forum response.

The efficacy of state heritage discourse and the tight control over sacred geography were marginal at best among the men with whom I regularly worked. There was little evidence for state-endorsed subjectivities. The Sufis I knew regularly, sometimes surreptitiously, visited both sites on pilgrimage. The saints buried at each location figured in the prayers the men offered upon their return. I heard stories told about both men. Along with other figures of more local and global acclaim, both Charkhi and Hamadoni were touchstones of what it meant to be a Tajik Muslim for the Sufi groups I knew who operated across Dushanbe and its wider environs. Museumification did not dissuade ritual or reverence, only how openly it was practiced. If anything, the state's appropriation of Hazrati Amirjon's legacy emphasised to Sufis the saint's wider importance. If he were important enough to merit a place on the country's 10-somoni currency note and to mention among the exemplars of Tajik history in state history books, then his shrine was well-due their special attention. I have written previously about how Sufis perpetuated state-endorsed notions about Tajik iden- 
tity, even as Sufis simultaneously utilised alternative histories from those celebrated in official discourse (Gatling 2018: 89-95). Stateproduced touristic shrine literature similarly had its place alongside the narratives Sufis told about Charkhi and Hamadoni, as if they too were potential fonts of spiritual wisdom.

The Sufi experiences I have referenced at Hazrati Amirjon and Hazrati Mavlono are admittedly gendered and anecdotal. I cannot be sure how or to what extent the experiences of the Sufis I knew are generalisable beyond the groups I studied or to other Muslims in the republic, or to Central Asia more generally. Still, I could provide other examples of pilgrimage and reverence for locally buried saints among Sufis in Tajikistan amidst the state's spectacular politics. I went multiple times with Sufis on pilgrimages to the burial place of a local pir, Khoja Orifi Regari, outside Tursunzoda, a site completely controlled by the Sufi groups I came to know well. I also repeatedly accompanied Sufi friends to the shrine of Makhdumi A"zam - a site housing the grave of an unknown 15th-century saint directly adjacent to Hisor fort, one of the largest tourist sites in the country and under the administration of the Ministry of Culture. The men I knew performed the same rituals at each site and held each saint in similar esteem, even as here too state regulation is lax and restrictions unevenly enforced.

Sufi shrine practices in Tajikistan suggest an important lacuna in ethnographic studies of the state and religious life in Muslim Eurasia; greater attention needs to be paid to less agonistic sites and responses to Central Asia's authoritarian regimes' securitisation of Islam. I am not suggesting that state interference into religious affairs is always seemingly detrimental to lived religious experience, just that state regulation may have no immediate effect on the devotion of practitioners even when public religious expression is tightly controlled. The performative shift in ethnographies of the state in Central Asia risks eliding the subjectivities of Central Asian Muslims into the social work of state specta- cle. Tajikistan's Sufis suggest how irrelevant Tajikistan's performative politics can sometimes be to the lives of individuals Muslims.

\section{Benjamin Gatling \\ (George Mason University)}

\section{References}

Adams, Laura. 2010. The Spectacular State: Culture and National Identity in Uzbekistan. Durham, NC: Duke University Press. DOI: https://doi. org/10.1215/9780822392538.

Féaux de la Croix, Jeanne. 2016. Iconic Places in Central Asia: The Moral Geography of Dams, Pastures and Holy Sites. Bielefeld: Transcript. DOI: https://doi.org/10.14361/9783839436301.

Gatling, Benjamin. 2018. Expressions of Sufi Culture in Tajikistan. Madison, WI: University of Wisconsin Press.

Kehl-Bodrogi, Krisztina. 2008. "Religion Is Not So Strong Here": Muslim Religious Life in Khorezm after Socialism. Berlin: Lit Verlag.

Louw, Maria Elisabeth. 2007. Everyday Islam in PostSoviet Central Asia. New York, NY: Routledge. DOI: https://doi.org/10.4324/9780203961773.

Muzaffarī, Muhammadalī; Hamza Kamol and Ză̌nuddin Nabotzoda 2007. Joŭhoi Muqaddasi Tojikiston. Dushanbe: Devashtich.

Privratsky, Bruce. 2001. Muslim Turkistan: Kazak Religion and Collective Memory. Richmond, Surrey: Curzon Press.

Rasanayagam, Johan. 2011. Islam in Post-Soviet Uzbekistan: The Morality of Experience. New York, NY: Cambridge University Press.

Reeves, Madeleine; Johan Rasanayagam and Judith Beyer, eds. 2014. Ethnographies of the State in Central Asia: Performing Politics. Bloomington, IN: Indiana University Press.

Schwab, Wendell and Ulan Bigozhin. 2016. Shrines and Neopatrimonialism in Southern Kazakhstan. - Kazakhstan in the Making: Legitimacy, Symbols, and Social Changes, edited by Marlene Laruelle. Lanham, MD: Lexington Books, 89-109.

Tasar, Eren. 2017. Soviet and Muslim: The Institutionalization of Islam in Central Asia. New York, NY: Oxford University Press. DOI: https://doi. org/10.1093/oso/9780190652104.001.0001. 